WANDA BARANOWSKA

Uniwersytet Łódzki

JUSTYNA LESZKA

Uniwersytet im. Adama Mickiewicza

w Poznaniu

\title{
AGRESYWNE ZACHOWANIA UCZNIÓW ZE SPE JAKO ŹRÓDŁA LĘKÓW NAUCZYCIELI. KORELACJA OSŁABIAJĄCA SUKCES EDUKACJI WŁĄCZAJĄCEJ
}

\begin{abstract}
AвSTRACT. Baranowska Wanda, Leszka Justyna, Agresywne zachowania uczniów ze SPE jako źródła lęków nauczycieli. Korelacja ostabiajaca sukces edukacji wtaczajacej [Students' with Sen Aggressive Behavior as the Source of Teachers' Fears. Correlation Weakening the Success of Inclusive Education]. Studia Edukacyjne nr 51, 2018, Poznań 2018, pp. 403-425. Adam Mickiewicz University Press. ISSN 1233-6688. DOI: $10.14746 /$ se.2018.51.24

In inclusive education, teachers work with all students, including those exhibiting aggressive behaviors. Today, many teachers struggle with challenging student behavior. The study aims to examine (1) aggressive behaviors in students with SPE - a source of teacher frustration in inclusive education, (2) the consequences of these behaviors triggering fears in teachers, and (3) the relationship between teacher seniority and likely consequences as per objective 2 .

The survey was conducted among 188 teachers. The data were analyzed using descriptive and correlational approaches. We determined that (1) the main source of teacher frustration is the physical aggression displayed by students with ASD, ADHD, ODD and CD; (2) the fear students with SEN may hurt other students is prominent amongst teachers, with a linear correlation between predictable consequences, where the strongest links appear between prediction of conflict in a classroom and the accusation of incompetence levelled at teachers by parents of students with SEN and between the fear of losing self-control and disapproval by superiors; (3) no significant relationship exists between the seniority of teachers and their perception of the sources of frustrations and fears. Against the background of the results, we formulated recommendations on inclusive education training for teachers.
\end{abstract}

Key words: inclusive education, student' aggressive behavior, teachers' frustration and fear 


\section{Wprowadzenie}

Edukacja włączająca toczy się w „teatrze” szkoły, w którym zostały przydzielone aktorom role; każdy z nich posiada określone kompetencje, pomiędzy aktorami zachodzi interakcja, a tło stanowi specjalnie przygotowana do spektaklu scenografia. Każdy aktor chce odnieść sukces, najlepiej jak umie kształtuje na scenie interakcje, ale czasem stresuje się i zmienia sposób odgrywania roli. Czy istnieje jakiś sposób, by mimo niepożądanych emocji sztuka odniosła sukces?

Sukces edukacji włączającej zależy od wielu czynników, wśród których ważne miejsce zajmuje kompetentny i pozytywnie nastawiony personel ${ }^{1}$. Kompetencje nauczycieli włączających są często omawiane w literaturze światowej. Uwagę zwraca się na konieczność posiadania przez nich wiedzy na temat potrzeb uczniów i sposobów ich zaspokajania, umiejętności pedagogicznych, także prezentowania adekwatnego do idei włączania systemu wartości, nastawień i oczekiwań ${ }^{2}$ W obszarze wartości podkreśla się szacunek dla różnorodności, wśród nauczycielskich umiejętności wiodące miejsce zajmuje wsparcie każdego ucznia ${ }^{3}$. Od wielu lat w badaniach światowych monitoruje się nastawienia nauczycieli szkół masowych i specjalnych do edukacji włączającej uczniów ze SPE${ }^{4}$, kontroluje poglądy i samoocenę ich kompetencji. Wyniki badań dowodzą, że nauczyciele wydają się pozytywnie nastawieni do idei włączenia i jednocześnie dostrzegają problemy w możliwościach jej praktycznej realizacji ${ }^{5}$. Znaczącym źródłem postrzeganych problemów jest

${ }^{1}$ J.A. Niemeyer, R. Proctor, The influence of experience on student teachers' beliefs about inclusion, Journal of Early Childhood Teacher Education, 2002, 23(1), s. 49-57; P.W. Wesley, V. Buysse, S. Tyndall, Family and professional perspectives on early intervention: An exploration using focus groups, Topics in Early Childhood Special Education, 1997, 17(4), s. 435-456; Z. Gajdzica, Opinie nauczycieli szkót ogólnodostępnych na temat edukacji włączającej uczniów z lekkim upośledzeniem umystowym w kontekście toczacej się reformy kształcenia specjalnego, [w:] Uczeń z niepetnosprawnościa, red. Z. Gajdzica, Sosnowiec 2011, s. 56-57.

2 R.D. Crick, Key Competencies for Education in a European Context: narratives of accountability or care, European Educational Research Journal, 2008, 7, s. 313; F. Caena, Teacher Competence Frameworks in Europe: policy-as-discourse and policy-as-practice, European Journal of Education, 2014, 49(3), s. 312.

${ }^{3}$ EADSNE: European Agency for Development in Special Needs Education, Profile of Inclusive Teachers, Odense, Denmark 2012, s. 7.

${ }^{4}$ D. Yasutake, J. Lerner, Teachers' Perceptions of Inclusion for Students with Disabilities: A Survey of General and Special Educators, Learning Disabilities: A Multidisciplinary Journal, 1996, 7(1), s. 1-7; S.E. Wigle, D.J. Wilcox, Teacher and administrator attitudes toward full inclusion in rural mid-America, Rural Special Education Quarterly, 1997, 16(1), s. 3-7; R.G. Monahan, S.B. Marino, R. Miller, Teacher attitudes toward inclusion: Implications for teacher education in schools 2000, Education, 1996, 117(2), s. 316-320; E.M. Unianu, Teachers' attitudes towards inclusive education, Procedia - Social and Behavioral Sciences, 2012, 33, s. 900-904.

${ }^{5}$ E. Avramidis, B. Norwich, Teachers' attitudes towards integration/inclusion: a review of the literature, European Journal of Special Needs Education, 2010, 17(2), s. 129-147; T.E. Scruggs, 
konieczność pracy z uczniami z trudnościami w zachowaniu, którzy negatywnie (silniej niż uczniowie z niepełnosprawnością intelektualną) wpływają na sprawność działania nauczycieli i rówieśników w klasie ${ }^{6}$. Nauczyciele klas masowych nie czują się przygotowani do pracy z nimi, odczuwają lęk, frustrację i złość, co osłabia ich pozytywne nastawienia do edukacji włączającej $^{7}$. Przegląd badań przeprowadzony przez De Boer, Pijl i Minnaert ${ }^{8}$ ujawnia, że większość nauczycieli szkół regularnych ma negatywne lub neutralne nastawienia do włączania uczniów ze SPE, co ma związek z ich doświadczeniem w pracy z takim uczniem, $\mathrm{z}$ typem niepełnosprawności ${ }^{9}$ i niedoborem szkolen $^{10}$. MacFarlane and Woolfson ${ }^{11}$ dowodzą w badaniach, że nauczyciele z mniejszym stażem pracy mają bardziej pozytywny stosunek do uczniów $\mathrm{z}$ trudnościami w zachowaniu (SEBD) ${ }^{12}$ niż nauczyciele $\mathrm{z}$ większym stażem. Badania Silva i Neves ${ }^{13}$ sugerują związek pomiędzy zakłócającym pracę zachowaniem uczniów a pedagogicznymi praktykami nauczycieli, co może łączyć się z nauczycielską atrybucją przyczyn zachowania uczniów ${ }^{14}$, także ze stanem odporności emocjonalnej nauczycieli, determinującej ich ogólny rozwój ${ }^{15}$.

M.A. Mastropieri, Teacher perceptions of mainstreaming inclusion, 1958-1995: A research synthesis, Exceptional Children, 1996, 63(1), s. 59-74.

${ }^{6}$ R.P. Hastings, S. Oakford, Student Teachers' Attitudes Towards the Inclusion of Children with Special Needs, Educational Psychology, 2003, 23, s. 87-94.

7 S. Chhabra, R. Srivastava, I. Srivastava, Inclusive education in Botswana: the perceptions of school teachers, Journal of Disability Policy Studies, 2010, 20, s. 219-228; B.G. Cook, D.L. Cameron, M. Tankersley, Inclusive teachers' attitudinal ratings of their students with disabilities, Journal of Special Education, 2007, 40(4), s. 230-238.

8 A. De Boer, S.J. Pijl, A. Minnaert, Regular primary schoolteachers' attitudes towards inclusive education: a review of the literature, International Journal of Inclusive Education, 2010, 15(3), s. 331-353.

${ }^{9}$ E. Avramidis, E. Kalyva, The influence of teaching experience and professional development on Greek teachers' attitudes towards inclusion, European Journal of Special Needs Education, 2007, 22(4), s. 367-389.

10 A.B. Kuyini i in., Ghanaian teachers: competencies perceived as important for inclusive education, International Journal of Inclusive Education, 2016, 20(10), s. 1009-1023.

${ }^{11}$ K. MacFarlane, L.M. Woolfson, Teacher attitudes and behavior toward the inclusion of children with social, emotional and behavioral difficulties in mainstream schools: An application of the theory of planned behaviour, Teaching and Teacher Education, 2013, 29, s. 46-52.

12 SEBD - pojęcie oznacza skrót social, emotional and behavioural difficulties - trudności społeczne, emocjonalne i w zachowaniu.

${ }^{13}$ P. Silva, I.P. Neves, Power and Control in the Classroom: Understanding Students' Disruptive Behaviours, Pedagogies: An International Journal, 2007, 2(4), s. 205-231.

${ }^{14}$ M. Poulou, B. Norwich, Cognitive, Emotional and Behavioural Responses to Students with Emotional and Behavioural Difficulties: A model of decision-making, British Educational Research Journal, 2010, 28(1), s. 111-138.

${ }^{15}$ C.F. Mansfield i in., "Don't sweat the small stuff: Understanding teacher resilience at the chalkface, Teaching and Teacher Education, 2012, 28(3), s. 357-367. 
Ważnym aspektem rozpoznawania uwarunkowań edukacji włączającej są emocje i afekty podmiotów w nią zaangażowanych. Zwróćmy uwagę, że emocje są wkomponowane w nauczycielskie nastawienia do idei włączania oraz w stosunek do ucznia z zaburzeniami zachowania, towarzyszą także codziennym interakcjom w szkole. Emocje są także pierwotnym źródłem niepożądanego zachowania ucznia ze SPE.

Emocje nauczyciela stanowią coraz częściej przedmiot badań, głównie z powodu poszukiwania czynników osłabiających wypalenie zawodowe. W świetle niektórych można zauważyć, że coraz wyższy poziom wymagań zewnętrznych wobec nauczycieli (oczekiwanie wysokich wyników, częste ich testowanie) podwyższa poziom stresu nauczycieli ${ }^{16}$. Wiadomo także, iż emocje nauczycieli są nierozerwalnie związane z emocjami uczniów ${ }^{17}$, kształtują jakość wzajemnie nawiązywanych relacji ${ }^{18}$.

Złość jest najczęściej rozpoznawaną negatywną emocją wśród nauczycie$\mathrm{li}^{19}$, która może być skierowana na ucznia lub do siebie ${ }^{20}$. Frenzel ${ }^{21}$ stwierdza, że nauczyciele mogą doświadczać złości wobec siebie, kiedy nie są usatysfakcjonowani swoim działaniem, mogą także odczuwać złość i niepokój z powodu złego zachowania uczniów, co jest prawdopodobnie jedną z najbardziej istotnych przyczyn tej emocji wśród nauczycieli. Nieprzyjemne emocje nauczycieli kojarzone są z łamaniem przez uczniów dyscypliny w klasie ${ }^{22}$ oraz poczuciem braku kompetencji w powstrzymywaniu i ograniczaniu takiego zachowania $^{23}$. Złość może pojawić się także wówczas, kiedy ktoś jest obwi-

${ }^{16}$ L. Valli, D. Buese, The changing roles of teachers in an era of high-stakes accountability, American Educational Research Journal, 2007, 44(3), s. 519-558.

17 D.K. Meyer, J.C. Turner, Re-conceptualizing emotion and motivation to learn in classroom contexts, Educational Psychology Review 2006, 18(4), s. 377-390.

18 J.S. Yoon, Teacher characteristics as predictors of teacher-student relationships: Stress, negative affect, and self-efficacy, Social Behavior and Personality: an international journal, 2002, 30(5), s. $485-493$.

19 R.E. Sutton, K.F. Wheatley, Teachers' emotions and teaching: A review of the literature and directions for future research, Educational Psychology Review, 2003, 15 (4), s. 327-358; R.E. Sutton, Teachers' anger, frustration, and self-regulation, [w:] Emotion in education, red. P.A. Schutz, R. Pekrun, San Diego 2007, s. 259-274; M-L. Chang, An appraisal perspective of teacher burnout: Examining the emotional work of teachers, Educational Psychology Review, 2009, 21 (3), s. 193-218.

20 P.C. Ellsworth, E.M.W. Tong, What does it mean to be angry at yourself? Categories, appraisals, and the problem of language, Emotion, 2006, 6 (4), s. 573-586.

21 A.C. Frenzel, Teacher Emotions, [w:] International Handbook of Emotions in Education, red. P.A. Alexander, R. Pekrun, L. Linnenbrik-Garcia, London 2014, s. 494-519.

22 A. Hargreaves, Mixed emotions: Teachers' perceptions of their interactions with students, Teaching and Teacher Education, 2000, 16, s. 811-826.

${ }_{23}$ M-L. Chang, H.A. Davis, Understanding the role of teacher appraisals in shaping the dynamics of their relationships with students: Deconstructing teachers' judgement of disruptive behavior/students, [w:] Advantages in teacher emotion research: The impact on teachers' lives, red. P.A. Schutz, M. Zembylas, New York 2009, s. 95-127. 
niany o niepożądane zdarzenia ${ }^{24}$, co w przypadku nauczycieli może oznaczać na przykład zarzut braku umiejętności zarządzania dyscypliną w klasie. Ponieważ doświadczanie i wyrażanie gniewu uważa się za społecznie niepożądane, szczególnie w przypadku nauczycieli ${ }^{25}$, wraz ze złością może pojawiać się lęk przed porażką i poczucie wstydu wobec niespełniania oczekiwań, wywołując ciągły niepokój ${ }^{26}$. Co ważne, i na co zwróciły uwagę badania Sutton ${ }^{27}$, wielu nauczycieli wyjaśnia, że: 1) mechanizm doświadczenia gniewu i frustracji nie jest generowany chwilowymi emocjami; są to intensywne, trwające dłużej niż godzinę stany związane z odczuwalnymi odczuciami cielesnymi, 2) ich gniew i frustracja prowadzi do zmian zachowania w klasie i strategii radzenia sobie z przebiegiem zajęć, czego przyczyn upatrują w natrętnych myślach utrudniających im koncentrację, 3) uczniowie są bezpośrednim celem ich gniewu i przyczyną frustracji. Oznacza to, że wpływ doświadczanych, negatywnych emocji może tworzyć stałą gotowość nauczycieli do gwałtownego reagowania na zachowanie ucznia, będącego sprawcą czynów uznanych przez nauczyciela za frustrujące.

Mając na uwadze odsetek występowania określonych zaburzeń w populacji ogólnej ${ }^{28}$, można założyć, że najliczniejszą grupę uczniów ze SPE w szkołach tworzą uczniowie z ADHD, autyzmem, w tym z zespołem Aspergera. Zachowania agresywne w tej grupie uczniów, choć występują częściej niż w przypadku uczniów z innymi zaburzeniami rozwojowymi, nie są objawem wpisanym w ich charakterystykę kliniczną ${ }^{29}$. Najczęstszym fenotypem w po-

24 P. Kuppens i in., The appraisal basis of anger: Specificity, necessity, and sufficiency of components, Emotion, 2003, 3(3), s. 254-269.

25 A. Liljestrom, K. Roulston, K. Demarrais, "There's No Place for Feeling Like This in the Workplace: Women Teachers' Anger in School Settings, [w:] Emotion in education, red. P.A. Schutz, R. Pekrun, San Diego, 2007, s. 275-291; R.E. Sutton, Teachers' anger, frustration, s. 259-274; R.E. Sutton, K.F. Wheatley, Teachers' emotions and teaching, s. 327-358.

26 A.G.C. Wright i in., The Pathoplastic Relationship Between Interpersonal Problems and Fear of Failure, Journal of Personality, 2009, 77(4), s. 997-1024; H.A. McGregor, A.J. Elliot, The Shame of Failure: Examining the Link Between Fear of Failure and Shame, Personality and Social Psychology Bulletin, 2005, 31(2), s. 218-231; A.J. Elliot, T.M. Thrash, The Intergenerational Transmission of Fear of Failure, Personality and Social Psychology Bulletin, 2004, 30(8), s. 957-971; A.J. Martin, H.W. Marsh, Fear of Failure: Friend or Foe?, Australian Psychologist, 2003, 38(1), s. 31-38.

27 R.E. Sutton, Teachers' anger, frustration, s. 259-274.

28 J. Fayyad i in., Cross-national prevalence and correlates of adult attention-deficit hyperactivity disorder, The British Journal of Psychiatry, 2007, 190 (5), s. 402-409; M. Elsabbagh i in., Global Prevalence of Autism and Other Pervasive Developmental Disorders, Autism Research, 2012, 5(3), s. $160-179$.

${ }^{29}$ S.E. Fitzpatrick i in., Aggression in autism spectrum disorder: presentation and treatment options, Neuropsychiatric Disease and Treatment, 2016, 12, s. 1525-1538; A. Hill i in., Aggressive Behavior Problems in Children with Autism Spectrum Disorders: Prevalence and Correlates in a Large Clinical Sample, Research in Autism Spectrum Disorders, 2014, 8(9), s. 1121-1133; D.F. Connor $\mathrm{i}$ in., Impulsive aggression in attention-deficit/hyperactivity disorder: Symptom severity, co-morbidity, 
pulacjach klinicznych, występującym u około 80\% agresywnych dzieci, jest agresja impulsywna, odwetowa ${ }^{30}$, wynikająca $\mathrm{z}$ frustracji, irytacji lub wrogości wobec rzeczywistych lub postrzeganych, generujących stres prowokacji. Jest nieplanowaną i natychmiastową odpowiedzią, odzwierciedlającą niekontrolowaną emocjonalność, która choć pozytywnie redukuje napięcie, to przynosi negatywne konsekwencje w ocenie społecznej agresora ${ }^{31}$.

Przytoczone wyniki badań rysują ogólny 'scenopis' oraz obraz problemów doznawanych przez 'aktorów' edukacji włączającej. Na tym tle zdecydowałyśmy rozpoznać szczegółowo źródła frustracji i lęków nauczycieli edukacji włączającej związane z agresywnym zachowaniem uczniów ze SPE.

\section{Metoda}

Badanie właściwe poprzedzono pilotażem w postaci 12 swobodnych wywiadów z nauczycielami zgłaszającymi się po poradę w sprawie zachowania agresywnego uczniów ze SPE (październik-listopad 2016). Wywiady zbierały wypowiedzi nauczycieli opisujące algorytm zachowania uczniów, nazywanego przez nauczycieli „zachowaniem agresywnym” oraz przewidywanych przez nauczycieli negatywnych konsekwencji tych zdarzeń. Wypowiedzi nauczycieli utworzyły katalog zmiennych w badaniach.

Badania właściwe przeprowadzono w okresie marzec 2017 - styczeń 2018. Ważne w nich było ustalenie: (1) jakie szczególne zachowania uczniów ze SPE są źródłem frustracji nauczycieli; (2) jakie zdarzenia, traktowane jako konsekwencje agresywnego zachowania uczniów ze SPE są źródłem obaw/lęków nauczycieli; (3) jaki związek istnieje pomiędzy postrzeganiem tych konsekwencji a stażem pracy nauczycieli. W zbieraniu danych posłużyłyśmy się sondażem z wykorzystaniem autorskiego kwestionariusza ankiety w dwóch identycznych treściowo wersjach - papierowej oraz online do samodzielnego wypełnienia przez badanych. Edycja internetowa została oparta na modelu Tailored Design Method - TDM ${ }^{32}$. Narzędzie zawierało pytania półotwarte

and attention-deficit/hyperactivity disorder subtype, Journal of Child Adolescent Psychopharmacology, 2010, 20(2), s. 119-126; P.S. Jensen i in., Consensus report on impulsive aggression as a symptom across diagnostic categories in child psychiatry: Implications for medication studies, Journal of the American Academy of Child and Adolescent Psychiatry, 2007, 46(3), s. 309-322.

${ }^{30} \mathrm{~F}$. Vitaro, M. Brendgen, R.E. Tremblay, Reactively and proactively aggressive children: Antecedent and subsequent characteristics, The Journal of Child Psychology and Psychiatry, 2002, 43 (4), s. 495-505.

${ }^{31}$ J.A. Hubbard i in., Reactive and proactive aggression in childhood and adolescence: Outcomes, processes, experiences, and measurement, Journal of Personality, 2010, 78 (1), s. 95-118.

32 D.A. Dillman, Mail and internet surveys: The tailored design method. Second Edition, Hoboken 2007. 
korespondujące z problemami badawczymi, dając badanym możliwość uzupełnienia wskazanych $\mathrm{w}$ kafeterii wartości zmiennych własnymi wypowiedziami. W badaniach zastosowałyśmy nieprobabilistyczny, arbitralny dobór próby. Kryterium były: (1) zatrudnienie w szkole różnego typu na stanowisku nauczyciela; (2) staż pracy minimum 1 rok; (3) udział w ostatnich dwóch latach w szkoleniu dotyczącym zaspokajania potrzeb uczniów ze SPE w edukacji włączającej. Do analizy danych wykorzystałyśmy 188 kwestionariuszy (w tym ponad $60 \% \mathrm{w}$ wersji papierowej). Próba jest homogeniczna ze względu na płeć - w badaniu wzięło udział jedynie 2 mężczyzn, także pod względem poziomu wykształcenia - wszyscy badani posiadają stopień magistra i pełne kwalifikacje do pracy w zawodzie nauczyciela, jak również uczestniczyli w szkoleniach związanych ze strategiami postępowania wobec agresji impulsywnej ucznia ze SPE w wymiarze od 3 do 8 godzin. Profil zawodowy nauczycieli uczestniczących w badaniu przedstawia tabela 1.

Tabela 1

Profil zawodowy uczestników badania

\begin{tabular}{|c|c|c|c|c|c|}
\hline \multirow{3}{*}{\multicolumn{2}{|c|}{ Staż pracy n-lat }} & \multicolumn{3}{|c|}{ Typ szkoły } & \multirow{3}{*}{ Razem } \\
\hline & & \multirow{2}{*}{$\begin{array}{l}\text { ogólna } \\
\text { liczba }\end{array}$} & \multirow{2}{*}{$\begin{array}{c}\text { włączająca } \\
\text { liczba }\end{array}$} & \multirow{2}{*}{$\begin{array}{c}\text { specjalna } \\
\text { liczba } \\
\end{array}$} & \\
\hline & & & & & \\
\hline & 1-10 lat & 29 & 25 & 1 & 55 \\
\hline & 11-17 lat & 15 & 20 & 4 & 39 \\
\hline & 18-24 lat & 20 & 17 & 8 & 45 \\
\hline & $>25$ & 22 & 20 & 7 & 49 \\
\hline Razem & & 86 & 82 & 20 & 188 \\
\hline
\end{tabular}

Statystyczne cechy grupy: 1) Staż min 1, max 40, mediana 17,5, średnia 10; 2) Typ szkoły: mediana 2,0 (włączająca), średnia 1 (szkoła ogólna/masowa).

Do analizy danych ankietowych wykorzystałyśmy dwa podejścia statystyczne - ustaliłyśmy częstość występowania wartości w obrębie zmiennych: a) zachowania uczniów ze SPE będące źródłem frustracji nauczycieli; b) przewidywane konsekwencje zachowania agresywnego uczniów wzmacniające frustrację nauczycieli. Następnie, po dychotomizacji i rangowaniu wyników surowych dotyczących przewidywanych konsekwencji, w podejściu korelacyjnym ustaliłyśmy ich współwystępowanie, z wykorzystaniem testu korelacji liniowej Spearmana. Ten sam test zastosowałyśmy ustalając korelację pomiędzy przewidywanymi konsekwencjami zachowań agresywnych uczniów a stażem pracy badanych nauczycieli. 


\section{Wyniki}

\section{Zachowania uczniów ze SPE jako źródła frustracji nauczycieli}

$\mathrm{W}$ badaniach poszukiwano danych o werbalnie i fizycznie agresywnym zachowaniu uczniów ze SPE, będącym źródłem frustracji nauczycieli, z dwóch perspektyw: 1) według typu zaburzeń i niepełnosprawności uczniów, z podziałem na dominującą formę agresji; 2) według czynów, jakie ci uczniowie popełniają. Należy dodać, że pojęciu „"zzęste” zachowania agresywne towarzyszył w kwestionariuszu opis: „te, które mają miejsce codziennie lub prawie codziennie".

Tabela 2 prezentuje dane dotyczące rozkładu agresywnie zachowujących się uczniów z różnymi typami SPE oraz dominującej w percepcji badanych formy agresji.

Tabela 2

Nauczycielska percepcja zachowań agresywnych uczniów ze SPE według typu SPE oraz dominującej formy agresji $(\mathrm{N}=188)$

\begin{tabular}{|l|c|c|c|c|c|c|}
\hline \multicolumn{1}{|c|}{ Uczniowie } & \multicolumn{2}{|c|}{$\begin{array}{c}\text { Częstość zachowa- } \\
\text { nia agresywnego }\end{array}$} & \multicolumn{2}{c|}{$\begin{array}{c}\text { Dominacja agresji } \\
\text { werbalnej }\end{array}$} & \multicolumn{2}{c|}{$\begin{array}{c}\text { Dominacja agresji } \\
\text { fizycznej }\end{array}$} \\
\hline Typ SPE & $\mathrm{n}$ & $\%$ & $\mathrm{n}$ & $\%$ & $\mathrm{n}$ & $\%$ \\
\hline Niedosłyszący i niesłyszący & 14 & $7 \%$ & 2 & $1 \%$ & 3 & $2 \%$ \\
\hline Niedowidzący i niewidzący & 4 & $2 \%$ & 2 & $1 \%$ & 2 & $1 \%$ \\
\hline Niepełnosprawność fizyczna & 14 & $7 \%$ & 2 & $1 \%$ & 1 & $1 \%$ \\
\hline $\begin{array}{l}\text { Lekki stopnień niepełno- } \\
\text { sprawności intelektualnej }\end{array}$ & 49 & $26 \%$ & 16 & $9 \%$ & 10 & $5 \%$ \\
\hline $\begin{array}{l}\text { Umiarkowany i znaczny } \\
\text { stopień niepełnosprawności } \\
\text { intelektualnej }\end{array}$ & 38 & $20 \%$ & 5 & $3 \%$ & 7 & $4 \%$ \\
\hline $\begin{array}{l}\text { Niepełnosprawność sprzę- } \\
\text { żona }\end{array}$ & 56 & $30 \%$ & 7 & $4 \%$ & 15 & $8 \%$ \\
\hline $\begin{array}{l}\text { Zaburzenia w spektrum } \\
\text { autyzmu (ASD) }\end{array}$ & 143 & $76 \%$ & 72 & $38 \%$ & 57 & $30 \%$ \\
\hline ADHD & 114 & $\mathbf{6 1} \%$ & 75 & $40 \%$ & 69 & $37 \%$ \\
\hline $\begin{array}{l}\text { Zaburzenia opozycyjno-bun- } \\
\text { townicze (ODD) }\end{array}$ & 119 & $\mathbf{6 3} \%$ & 48 & $26 \%$ & 42 & $22 \%$ \\
\hline $\begin{array}{l}\text { Zaburzenia zachowania } \\
\text { (CD) }\end{array}$ & 117 & $\mathbf{6 2} \%$ & 53 & $28 \%$ & 40 & $21 \%$ \\
\hline \multicolumn{1}{|c|}{ Zachowania ryzykowne } & 112 & $60 \%$ & 38 & $20 \%$ & 28 & $15 \%$ \\
\hline
\end{tabular}




\begin{tabular}{|l|c|c|c|c|c|c|}
\hline \multicolumn{1}{|c|}{ Wykluczenie społeczne } & 109 & $58 \%$ & 42 & $22 \%$ & 55 & $29 \%$ \\
\hline Zaburzenia w uczeniu się & 16 & $9 \%$ & 5 & $3 \%$ & 0 & $0 \%$ \\
\hline Choroba przewlekła & 6 & $3 \%$ & 0 & $0 \%$ & 4 & $2 \%$ \\
\hline Zdolni i utalentowani & 8 & $4 \%$ & 2 & $1 \%$ & 0 & $0 \%$ \\
\hline Imigranci & 1 & $1 \%$ & 1 & $1 \%$ & 0 & $0 \%$ \\
\hline
\end{tabular}

Uwaga: n nie sumuje się do łącznej liczby badanych $(\mathrm{N}=188)$, ponieważ pytanie zawierało możliwość wyboru wielu odpowiedzi.

Ogólny obraz częstości zachowań agresywnych uczniów postrzeganych przez nauczycieli w poszczególnych typach SPE potwierdza wcześniejsze badania dotyczące skali i współwystępowania zachowań agresywnych w ADHD, CD i ODD ${ }^{33}$ oraz w ASD ${ }^{34}$. Badani z prawie równą częstością wskazują również uczniów społecznie odrzuconych oraz podejmujących zachowania ryzykowne (wagarujących, pijących alkohol), jednak należy zwrócić uwagę, że genezą odrzucenia oraz zachowań ryzykownych bardzo często bywa ADHD i zaburzenia współwystępujące ${ }^{35}$. Sięgając do wyników surowych widzimy, że wskazania te poczynili głównie nauczyciele uczniów w wieku 12-15 lat i powyżej 15. roku życia, kiedy mamy do czynienia z odrzuceniem, jako „powikłaniami” ADHD ${ }^{36}$.

Badania Kanne i Mazurek ${ }^{37}$ wskazują zachowania agresywne wobec opiekunów u 68\% uczniów z ASD, inne natomiast donoszą, że częstość

33 A.E. Angold, J. Costello, A. Erkanli, Comorbidity, Journal of Child Psychology and Psychiatry, 1999, 40(1), s. 57-87; V.A. Johnson i in., Childhood-versus Adolescent-Onset Antisocial Youth with Conduct Disorder: Psychiatric Illness, Neuropsychological and Psychosocial function, PLoS ONE 2015, 10(4):e0121627. https:/ / dx.doi.org/10.1371\%2Fjournal.pone.0121627, [dostęp: 20.03.2018].

${ }^{34}$ L. Lecavalier, S. Leone, J. Wiltz, The impact of behaviour problems on caregiver stress in young people with autism spectrum disorders, Journal of Intellectual Disability Research, 2006, 50 (Pt3):172-183. https://doi.org/10.1111/j.1365-2788.2005.00732.x. [dostęp: 21.03.2018]; V. Totsika i in., A population-based investigation of behavioural and emotional problems and maternal mental health: associations with autism spectrum disorder and intellectual disability, The Journal of Child Psychology and Psychiatry, 2011, 52(1), s. 91-99.

35 N-M. Bakhshani, Attention-Deficit/Hyperactivity Disorder (ADHD) and High Risk Behaviors, International Journal of High Risk Behaviors \& Addiction, 2013, 2(1), s. 1-2; J.S. Nijmeijer i in., Attention-deficit/hyperactivity disorder and social dysfunctioning, Clinical Psychology Review, 2008, 28(4), s. 692-708.

36 J.S. Nijmeijer i in., Attention-deficit/hyperactivity disorder, s. 692-708; S. Mrug i in., Peer Rejection and Friendships in Children with Attention-Deficit/Hyperactivity Disorder: Contributions to Long-Term Outcomes, Journal of Abnormal Child Psychology, 2012, 40(6), s. 1013-1026; K.E. Saylor, B.H. Amann, Impulsive Aggression as a Comorbidity of Attention-Deficit/Hyperactivity Disorder in Children and Adolescents, Journal of Child and Adolescent Psychopharmacology, 2016, 26(1), s. $19-25$.

37 S.M. Kanne, M.O. Mazurek, Aggression in Children and Adolescents with ASD: Prevalence and Risk Factors, Journal of Autism and Developmental Disorders, 2011, 41(7), s. 926-937. 
występowania agresji fizycznej u dzieci z ASD wynosi 53\% ${ }^{38}$. Intensywnie rosnąca $\mathrm{w}$ ostatniej dekadzie liczba dzieci z zaburzeniami $\mathrm{w}$ spektrum autyzmu ${ }^{39}$ oznacza wzrost częstości agresywnych zachowań tych uczniów, co może uzasadniać wyższy wynik postrzegania tych uczniów jako „osobowe” źródła frustracji badanych nauczycieli.

Clough i Lindsay w 1991 roku donosili ${ }^{40}$, że większość nauczycieli uznaje potrzeby dzieci z zaburzeniami emocjonalnymi i behawioralnymi za najtrudniejsze do spełnienia [zatem frustrujące - przyp. autorek]; na kolejnych miejscach nauczyciele lokują dzieci z trudnościami w uczeniu się, z wadami wzroku, wadą słuchu. Jak widać, w ciągu ostatnich ponad 20 lat pierwszoplanowa trudność zostaje na tym samym miejscu, co potwierdzają wyniki naszych badań. Diametralnie zmieniła się pozycja uczniów z innymi typami SPE. Edukacja włączająca $w$ świetle wyników jest wyraźnie zdominowana trudnością pracy z dzieckiem nie radzącym sobie z kontrolą emocji, zachowującym się agresywnie. $Z$ pewnością zakłóca to przebieg procesu nauczania i mimo wieloletnich starań podmiotów decydujących o całokształcie oraz uczestniczących w edukacji integracyjnej i włączającej, wydaje się z jednej strony niemożliwe do zlikwidowania, z drugiej trudne do zaakceptowania. W naszej opinii sytuacja wymaga intensywniejszego rozpoznania „w głąb” algorytmów ją kreujących.

W ciągu kilkunastoletniej działalności diagnostycznej i naukowej bardzo często słyszymy od rodziców uczniów z ASD i ADHD, że "nauczyciele są nadwrażliwi”, a "dzieci przecież nic takiego złego nie robią". W badaniach postanowiłyśmy skonfrontować te opinie i sprawdzić, jakie czyny uczniów ze SPE są uznane za agresywne i stają się bezpośrednim źródłem frustracji nauczycieli. Wyniki, prezentowane $\mathrm{w}$ tabeli 3 , są niepokojące.

Jeśli codziennie lub prawie codziennie dochodzi w klasie do czynów popełnianych przez ucznia/uczniów z SEN, które ilustrują wyniki, trudno dziwić się nauczycielskiej frustracji, jak też założyć harmonijność przebiegu procesu nauczania. Kilkoro badanych (w tym czworo zastąpiło nimi wskazanie wartości wymienionych w kafeterii pytania) do listy czynów uczniów uznanych za agresywne dodało „samowolne opuszczanie sali lekcyjnej w czasie wybuchu złości".

38 M.O. Mazurek, S.M. Kanne, E.L. Wodka, Physical aggression in children and adolescents with autism spectrum disorders, Research in Autism Spectrum Disorders, 2013, 7(3), s. 455-465.

39 C.J. Newschaffer i in., The Epidemiology of Autism Spectrum Disorders, Annual Review of Public Health, 2007, 28, s. 235-258; K. Lyall i in., The Changing Epidemiology of Autism Spectrum Disorders, Annual Review of Public Health, 2017, 38, s. 81-102.

40 P. Clough, G. Lindsay, Integration and the Support Service. Changing Roles in Special Education, Routledge, Slough Winsdor, 1991, NFER-NELSON (2004, Taylor \& Francis e-Library). 
Obserwowane zachowania agresywne uczniów ze SPE jako źródła nauczycielskiej frustracji $(\mathrm{N}=184)$

\begin{tabular}{|c|c|c|c|c|c|c|c|c|c|c|}
\hline \multirow[b]{2}{*}{ 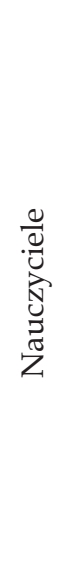 } & \multicolumn{7}{|c|}{ Akty agresji fizycznej } & \multicolumn{3}{|c|}{ Akty agresji werbalnej } \\
\hline & 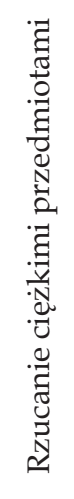 & 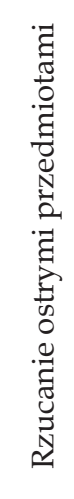 & 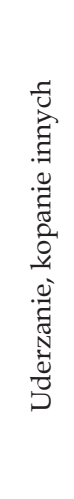 & 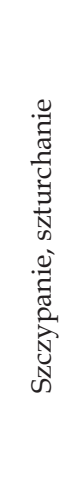 & 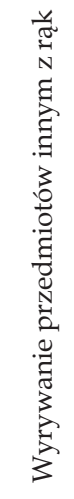 & 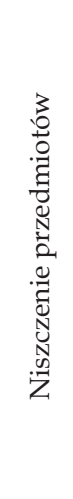 & 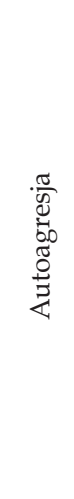 & 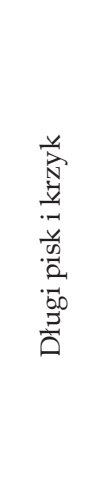 & 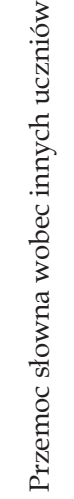 & 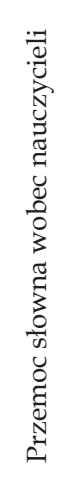 \\
\hline $\mathrm{N}$ & 120 & 115 & 119 & 77 & 44 & 83 & 91 & 56 & 91 & 58 \\
\hline$\%$ & $65 \%$ & $63 \%$ & $65 \%$ & $42 \%$ & $24 \%$ & $45 \%$ & $49 \%$ & $30 \%$ & $49 \%$ & $32 \%$ \\
\hline
\end{tabular}

Niestety, nie znalazłyśmy wyników badań, do których mogłybyśmy wprost przyrównać dane. Zwróćmy jednak uwagę, że w przypadku uczniów z ASD mamy do czynienia z zaburzeniami rozumienia emocji innych osób oraz z nieprawidłową regulacją własnych, co jest istotnym czynnikiem występowania agresywnego zachowania i co potwierdzają badania Pouw i współautorów ${ }^{41}$. W sytuacji szkolnej każda interakcja pomiędzy uczniem z ASD a nauczycielem i rówieśnikami będzie zatem „napiętnowana” cechą kliniczną. Dynamika wymiany emocji w klasie szkolnej niesie ryzyko częstego zachowania o charakterze agresywnym, co potwierdza uzyskany w naszych badaniach wynik. Badania Mazurek i współautorów ${ }^{42}$ ujawniają, że agresja fizyczna uczniów z ASD jest w znacznym stopniu związana z szeregiem cech klinicznych, wśród których wymienia się jako pierwszoplanowe samouszkodzenia, z czym także mamy do czynienia w wynikach. W badaniu Pugliese i współautoró $w^{43}$ dowiedziono także, że poziom agresywności dzieci wysoko

${ }^{41}$ L.B. Pouw i in., Reactive/proactive aggression and affective/cognitive empathy in children with ASD, Research in Developmental Disabilities, 2013, 34(4), s. 1256-1266.

${ }^{42}$ M.O. Mazurek, S.M. Kanne, E.L. Wodka, Physical aggression in children and adolescents with autism, s. 455-465.

43 C.E. Pugliese i in., Social Anxiety Predicts Aggression in Children with ASD: Clinical Comparisons with Socially Anxious and Oppositional Youth, Journal of Autism and Developmental Disorders, 2013, 43(5), s. 1205-1213. 
funkcjonujących z ASD jest współmierny z poziomem prezentowanym przez dzieci z ODD/CD. Podobnie w przypadku ADHD, gdzie ponad 50\% uczniów wykazuje istotną, demonstrowaną w zachowaniu agresję impulsywną, która staje się przyczyną odrzucenia przez rówieśników ${ }^{44}$. Oznacza to i nie zaskakuje, że w przypadku badanych nauczycieli częstość występowania zachowania agresywnego uczniów ze SPE jest na tyle wysoka, że stanowi istotne źródło frustracji i zakłóca dyscyplinę w klasie. W takiej sytuacji pojawia się także u nauczycieli złość i lęk $k^{45}$.

\section{Konsekwencje agresywnego zachowania uczniów ze SPE jako źródło lęków nauczycieli}

Nauczyciele włączający są (a przynajmniej powinni być) kognitywnie przygotowani do pracy z uczniami ze SPE. Wiedza o współwystępowaniu ryzyka zachowań agresywnych wśród grup uczniów z ASD, ADHD, ODD i CD jest wiedzą masowo upowszechnianą we wszystkich obszarach geograficznych. Choć frustracja związana z możliwym do przewidzenia agresywnym zachowaniem ucznia jest uzasadniona, to założyłyśmy w badaniach, że istnieją w pracy nauczyciela czynniki (sytuacje, działania innych podmiotów uczestniczących w edukacji włączającej), które wzmacniają doznawane frustracje lub generują poczucie zagrożenia nauczycieli (wywołują stan lęku). Na użytek badań nazwałyśmy je konsekwencjami zachowań agresywnych uczniów, ich wybór ograniczyłyśmy w badaniu do czterech najsilniej przewidywanych (nie doświadczanych) przez nauczycieli, prosiłyśmy o przyporządkowanie im natężenia odczuwanego lęku. Rozkład przewidywanych zdarzeń pod względem siły odczuwanego lęku zawiera tabela 4.

Przewidywanie silnego konfliktu pomiędzy uczniami oraz oskarżeń rodziców dzieci bez SPE o brak kompetencji (zaniedbania w pracy) może wyzwalać u nauczycieli poczucie wstydu wobec niespełniania oczekiwań, pojawiającego się także jako indywidualna strategia samoregulacji i łagodzenia złości ${ }^{46}$. Blisko jedna trzecia badanych obawia się eskalacji wtasnych emocji i utraty samokontroli.

${ }^{44}$ K.E. Saylor, B.H. Amann, Impulsive Aggression as a Comorbidity of Attention-Deficit/Hyperactivity Disorder in Children and Adolescents, Journal of Child and Adolescent Psychopharmacology, 2016, 26(1), s. 19-25.

45 R.E. Sutton, Teachers' anger, frustration, s. 259-274; M.M. Keller i in., Teachers' emotional experiences and exhaustion as predictors of emotional labor in the classroom: an experience sampling study, Frontiers in Psychology, 2014, 5, s. 1442.

46 A.G.C. Wright i in., The Pathoplastic Relationship Between Interpersonal Problems, s. 9971024. 
Podobna liczba nauczycieli obawia się zranienia ze strony uczniów ze SPE, co może prowokować także lęk przed doznawaniem fizycznego bólu.

Przewidywane konsekwencje zachowania agresywnego uczniów jako źródła nauczycielskich lęków $(\mathrm{N}=188)$

\begin{tabular}{|c|c|c|c|c|c|c|c|c|c|c|c|c|c|c|}
\hline \multirow{3}{*}{$\begin{array}{l}\text { Natę- } \\
\text { żenie } \\
\text { lęku }\end{array}$} & \multicolumn{14}{|c|}{ Przewidywane zdarzenia } \\
\hline & \multicolumn{2}{|c|}{$\begin{array}{l}\text { Zranienie } \\
\text { rówieśni- } \\
\text { ków }\end{array}$} & \multicolumn{2}{|c|}{$\begin{array}{c}\text { Silny } \\
\text { konflikt } \\
\text { pomiędzy } \\
\text { uczniami }\end{array}$} & \multicolumn{2}{|c|}{$\begin{array}{c}\text { Zranienie } \\
\text { nauczy- } \\
\text { ciela }\end{array}$} & \multicolumn{2}{|c|}{$\begin{array}{c}\text { Eskalacja } \\
\text { emocji na- } \\
\text { uczyciela, } \\
\text { utrata } \\
\text { samokon- } \\
\text { troli }\end{array}$} & \multicolumn{2}{|c|}{$\begin{array}{l}\text { Zarzuty } \\
\text { braku } \\
\text { kompe- } \\
\text { tencji ze } \\
\text { strony } \\
\text { rodziców } \\
\text { uczniów } \\
\text { bez SPE }\end{array}$} & \multicolumn{2}{|c|}{$\begin{array}{l}\text { Zarzuty } \\
\text { braku } \\
\text { kompe- } \\
\text { tencji ze } \\
\text { strony } \\
\text { rodziców } \\
\text { uczniów } \\
\text { ze SPE }\end{array}$} & \multicolumn{2}{|c|}{$\begin{array}{c}\text { Zarzuty } \\
\text { braku kom- } \\
\text { petencji } \\
\text { ze strony } \\
\text { przełożo- } \\
\text { nych }\end{array}$} \\
\hline & $\mathrm{N}$ & $\%$ & $\mathrm{~N}$ & $\%$ & $\mathrm{~N}$ & $\%$ & $\mathrm{~N}$ & $\%$ & $\mathrm{~N}$ & $\%$ & $\mathrm{~N}$ & $\%$ & $\mathrm{~N}$ & $\%$ \\
\hline $\begin{array}{c}1 \\
(\max ) \\
\end{array}$ & 120 & $64 \%$ & 13 & $7 \%$ & 2 & $1 \%$ & 26 & $14 \%$ & 21 & $11 \%$ & 3 & $2 \%$ & 6 & $3 \%$ \\
\hline 2 & 25 & $13 \%$ & 30 & $16 \%$ & 21 & $11 \%$ & 18 & $10 \%$ & 44 & $10 \%$ & 8 & $4 \%$ & 9 & $5 \%$ \\
\hline 3 & 12 & $6 \%$ & 28 & $15 \%$ & 21 & $11 \%$ & 10 & 370 & 18 & $5 \%$ & 26 & $14 \%$ & 7 & $4 \%$ \\
\hline 4 & 3 & $2 \%$ & 16 & $9 \%$ & 14 & $7 \%$ & 1 & $1 \%$ & 8 & $1 \%$ & 3 & $2 \%$ & 8 & $4 \%$ \\
\hline Razem & 160 & $85 \%$ & 87 & $46 \%$ & 58 & $31 \%$ & 55 & $29 \%$ & 91 & $27 \%$ & 40 & $21 \%$ & 30 & $16 \%$ \\
\hline
\end{tabular}

Z dużą ostrożnością (nasze badania koncentrowały się na identyfikacji, nie analizie źródeł lęku) możemy przypuścić, że w każdym przewidywanym zdarzeniu mamy do czynienia $\mathrm{z}$ podobnym znakiem emocji (negatywne), kierunkiem (pobudzenie) i skutkiem, polegającym na zakłóceniu zachowania nauczycieli, które może przyczynić się do stworzenia nieprzewidywalnego dla uczniów ze SPE środowiska, i co z kolei może negatywnie wpłynąć na ich emocje ${ }^{47}$. Przewidywane zdarzenia, rozumiane jako źródła lęku nauczycieli, współwystępują w badanej grupie ze sobą, tworząc wzmocnienia odczuwanych frustracji. Kształtują też zapewne zachowanie nauczycieli w czasie zajęć.

Wszystkie przewidywane przez nauczycieli zdarzenia wiążą się wzajemnie, choć z różną siłą, zatem mamy do czynienia z pewną "grą lęków".

47 R.E. Sutton, Teachers' anger, frustration, s. 259-274; L.B. Pouw i in., Reactive/proactive aggression and affective/cognitive empathy, s. 1256-1266. 
Tabela 5

Współczynnik korelacji Spearmana

pomiędzy przewidywanymi konsekwencjami zachowania agresywnego uczniów

\begin{tabular}{|c|c|c|c|c|c|c|c|c|}
\hline \multicolumn{2}{|c|}{ Współczynnik Spearmana } & 1 & 2 & 3 & 4 & 5 & 6 & 7 \\
\hline \multirow{2}{*}{$\begin{array}{l}\text { 1. Zranienie } \\
\text { rówieśników }\end{array}$} & Rho & 1,000 & $428^{* *}$ & 0,235 &,$- 731^{\star *}$ &,$- 403^{\star *}$ &,$- 730^{* *}$ & $-0,391$ \\
\hline & $\mathrm{N}$ & 160 & 70 & 53 & 43 & 78 & 35 & 24 \\
\hline \multirow{2}{*}{$\begin{array}{l}\text { 2. Silny konflikt } \\
\text { pomiędzy } \\
\text { uczniami }\end{array}$} & Rho & & 1,000 & $-0,134$ & $-0,173$ &,$- 393^{*}$ &,$- 852^{* *}$ & 0,235 \\
\hline & $\mathrm{N}$ & & 87 & 30 & 28 & 32 & 9 & 8 \\
\hline \multirow{2}{*}{$\begin{array}{l}\text { 3. Zranienie } \\
\text { nauczyciela }\end{array}$} & Rho & & & 1,000 & $-0,250$ & $-0,293$ & $-0,258$ & $-0,344$ \\
\hline & $\mathrm{N}$ & & & 58 & 17 & 22 & 7 & 5 \\
\hline \multirow{2}{*}{$\begin{array}{l}\text { 4. Eskalacja emocji } \\
\text { nauczyciela, } \\
\text { utrata } \\
\text { samokontroli }\end{array}$} & Rho & & & & 1,000 & $-0,104$ & 0,655 &,$- 894^{*}$ \\
\hline & $\mathrm{N}$ & & & & 55 & 22 & 8 & 6 \\
\hline \multirow{2}{*}{$\begin{array}{l}\text { 5. Zarzuty braku } \\
\text { kompetencji } \\
\text { ze strony } \\
\text { rodziców uczniów } \\
\text { bez SPE }\end{array}$} & Rho & & & & & 1,000 &, $718^{* *}$ & $-0,394$ \\
\hline & $\mathrm{N}$ & & & & & 91 & 32 & 21 \\
\hline \multirow{2}{*}{$\begin{array}{l}\text { 6. Zarzuty braku } \\
\text { kompetencji } \\
\text { ze strony } \\
\text { rodziców uczniów } \\
\text { ze SPE }\end{array}$} & Rho & & & & & & 1,000 &, $749^{* *}$ \\
\hline & $\mathrm{N}$ & & & & & & 40 & 15 \\
\hline \multirow{2}{*}{$\begin{array}{l}\text { 7. Zarzuty braku } \\
\text { kompetencji } \\
\text { ze strony } \\
\text { przełożonych }\end{array}$} & Rho & & & & & & & 1,000 \\
\hline & $\mathrm{N}$ & & & & & & & 30 \\
\hline
\end{tabular}

* Korelacja istotna na poziomie at 0,05 (obustronnie).

** Korelacja istotna na poziomie 0,01 (obustronnie). 
Analizę korelacji przeprowadziłyśmy $\mathrm{w}$ dwóch grupach przewidywanych zdarzeń: pierwsza to zdarzenia "agresywne" z udziałem uczniów (pozycje 1-3 w tabeli 5), druga to zdarzenia związane $\mathrm{z}$ oceną nauczycieli przez rodziców i przełożonych (pozycje 5-7), wychodząc w obu grupach od przewidywania "utraty samokontroli przez nauczyciela” (czynnik 4). Pod szczególną uwagę wzięłyśmy zdarzenia, dla których współczynnik korelacji Spearmana przyjmuje wartość powyżej +/- 0,6.

W pierwszej grupie czynników mamy do czynienia z sytuacją, w której nauczyciel im silniej obawia się zranienia ucznia przez dziecko ze SPE, tym słabiej przewiduje utratę samokontroli (Rho -0,731), słabiej monitoruje rozwój własnych emocji, co oznacza niewysoki poziom samoświadomości emocjonalnej. $Z$ taką sytuacją spotykamy się w przypadku $85 \%$ badanych nauczycieli. Choć fakt tego wiązania nie dowodzi utraty samokontroli nauczycieli w sytuacji realnej, to na podstawie wyników innych badań możemy postawić tezę wysokiego prawdopodobieństwa wystąpienia w niej reakcji impulsywnych nauczyciela, niezgodnych z obiektywnymi potrzebami sytuacji. Przegląd badań wykonany przez Jennings i Greenberg ${ }^{48}$ wykazał, że samoświadomość emocjonalna pozwala nauczycielom na przewidywanie skutków ich ekspresji emocjonalnej, kształtującej interakcje. Co więcej, od poziomu samoświadomości nauczyciela zależy zdolność regulacji emocji w interakcjach z uczniami i reagowania na sytuacje w sposób wyrażający troskę i empatię ${ }^{49}$.

W drugiej grupie czynników widzimy, że nauczyciel, który ze wzrostem siły obaw przed utratą samokontroli silniej będzie "włączał" obawę przed negatywną oceną swoich kompetencji przez rodziców uczniów ze SPE (Rho 0,655 ), na początku usunie obawę przed negatywną oceną przełożonych (Rho $-0,894)$. Bardzo prawdopodobne $\mathrm{w}$ tej sytuacji, że nauczyciel będzie mimowolnie sterował sytuacją tak, by zabezpieczyć się przed oskarżeniami rodziców i tym samym uniknąć poczucia braku kompetencji wywołującego złośćso. Wyniki badań nie wyjaśniają jednak, czy oznacza to podjęcie jakiejkolwiek próby przeciwdziałania agresji ucznia ze SPE, czy też zaniechanie wszelkich

${ }^{48}$ P.A. Jennings, M.T. Greenberg, The prosocial classroom: Teacher social and emotional competence in relation to student and classroom outcomes, Review of Educational Research, 2009, 79 (1), s. 491-525.

${ }^{49}$ M.A. Brackett i in., A sustainable, skill-based approach to building emotionally literate schools, [w:] Handbook for Developing Emotional and Social Intelligence: Best Practices, Case Studies, and Strategies, red. M. Hughes, H.L. Thompson, J.B. Terrell, CA: Pfeiffer, San Francisco 2009, s. 329-358; C. Perry, I. Ball, Dealing constructively with negatively evaluated emotional situations: the key to understanding the different reactions of teachers with high and low levels of emotional intelligence, Social Psychology of Education, 2007, 10(4), s. 443-454.

${ }^{50}$ M-L. Chang, H.A. Davis, Understanding the role of teacher appraisals in shaping the dynamics of their relationships with students: Deconstructing teachers' judgement of disruptive behavior/students, [w:] Advantages in teacher emotion research: The impact on teachers' lives, red. P.A. Schutz, M. Zembylas, New York 2009, s. 95-127. 
działań w wyniku silnej frustracji. Nie wiemy też, czy hipotetycznie podjęta próba uspokojenia agresji ucznia ze SPE odpowie na potrzeby tego dziecka.

Współczynnik Spearmana w przeprowadzonych badaniach informuje także o tym, że wzrost siły obaw przed oskarżeniami rodziców uczniów ze SPE koreluje dodatnio z siłą obaw przed dezaprobatą przełożonych (Rho 0,749 ) oraz z zarzutem lekceważenia sytuacji stawianym nauczycielom przez rodziców dzieci nieagresywnych (Rho 0,718). Napięcie emocjonalne nauczyciela związane z przewidywaniem konfliktu pomiędzy uczniami wchodzi z kolei w silną ujemną korelację z lękiem przed "pretensjami” rodziców uczniów ze SPE (Rho -0,852). W każdym z wariantów tej "gry lęków" autorytet zewnętrzny (nieobecny fizycznie w klasie) może wzmacniać frustrację nauczyciela związaną z doświadczaniem złości w obliczu złego zachowania ucznia $^{51}$.

\section{Staż pracy a postrzeganie konsekwencji agresywnego zachowania uczniów z SEN jako źródeł lęku nauczycieli}

Współczynnik korelacji liniowej Spearmana osiągnął znikomą wartość dla wiązania każdej z przewidywanych konsekwencji i stażu pracy, co ilustruje tabela 6 .

Tabela 6

Współczynnik korelacji Spearmana

pomiędzy przewidywanymi zdarzeniami a stażem pracy badanych

\begin{tabular}{|c|c|c|c|c|c|c|c|}
\hline \multicolumn{2}{|c|}{ Przewidywane zdarzenia } \\
\hline $\begin{array}{c}\text { Staż } \\
\text { ba- } \\
\text { da- } \\
\text { nych }\end{array}$ & $\begin{array}{c}\text { Zranienie } \\
\text { rówieśni- } \\
\text { ków }\end{array}$ & $\begin{array}{c}\text { Silny } \\
\text { konflikt } \\
\text { pomiędzy } \\
\text { uczniami }\end{array}$ & $\begin{array}{c}\text { Zranienie } \\
\text { nauczy- } \\
\text { ciela } \\
\text { eskalacja } \\
\text { nauczy- } \\
\text { ciela, } \\
\text { utrata } \\
\text { samokon- } \\
\text { troli }\end{array}$ & $\begin{array}{c}\text { Zarzuty } \\
\text { braku } \\
\text { kompe- } \\
\text { tencji ze } \\
\text { strony } \\
\text { rodziców } \\
\text { uczniów } \\
\text { bez SPE }\end{array}$ & $\begin{array}{c}\text { Zarzuty } \\
\text { braku } \\
\text { kompe- } \\
\text { tencji ze } \\
\text { strony } \\
\text { rodziców } \\
\text { uczniów } \\
\text { ze SPE }\end{array}$ & $\begin{array}{c}\text { Za- } \\
\text { rzuty } \\
\text { braku } \\
\text { kom- } \\
\text { peten- } \\
\text { cji ze } \\
\text { strony } \\
\text { prze- } \\
\text { łożo- } \\
\text { nych }\end{array}$ \\
\hline Rho &, $210^{*}$ & 0,042 & $-0,167$ & $-0,157$ & 0,073 & 0,033 & $-0,033$ \\
\hline $\mathrm{N}$ & 160 & 87 & 58 & 55 & 91 & 40 & 30 \\
\hline
\end{tabular}

* - korelacja istotna na poziomie 0.01 (obustronnie).

${ }^{51}$ A.C. Frenzel, Teacher Emotions, s. 494-519; P. Kuppens i in., The appraisal basis of anger, s. $254-269$. 
Stwierdzamy zatem, że nie występuje istotny związek pomiędzy stażem pracy nauczycieli a przewidywaniem przez nich konsekwencji zachowania agresywnego uczniów ze SPE jako źródeł lęków.

\section{Dyskusja}

Wyniki ujawniły, że nauczyciele obserwują frustrujące ich zachowanie najliczniej u uczniów z ASD (blisko 80\% badanych); uczniowie z ODD, CD, ADHD, zachowaniem ryzykownym oraz społecznie wykluczeni stanowią grupę, w której zachowaniu źródła własnej frustracji postrzega około 60\% nauczycieli, co w zasadzie potwierdza częstość współwystępowania agresji w wymienionych typach zaburzen ${ }^{52}$. Zachowania te zakłócają dyscyplinę w klasie, generują większą intensywność emocji nauczycieli, co może zgodnie z wynikami badań Tsoupoupas i współautorów ${ }^{53}$ zwiastować ich emocjonalne wyczerpanie. Taki stan osłabia obiektywne postrzeganie zdarzeń oraz odporność nauczycieli ${ }^{54}$. Nasila z kolei przewidywanie różnych zdarzeń (konsekwencji zachowania agresywnego uczniów ze SPE) jako wtórnych i lękotwórczych dla nauczyciela, co ujawniły wyniki badań własnych. Obawa przed eskalacją emocji i utratą samokontroli wynikać może z przekonania nauczycieli o niemożności wyrażania gniewu, na co zwracały uwagę wcześniejsze badania Liljestrom, Roulston i deMarrais ${ }^{55}$, Sutton ${ }^{56}$, Sutton i Wheatley ${ }^{57}$. Wiążący się z obawą utraty samokontroli w naszych badaniach lęk przed dezaprobatą rodziców i przełożonych (zarzut braku kompetencji) jest innym wyrazem lęku przed porażką i poczuciem wstydu wobec niespełniania oczekiwań opisywanym przez Wright i współautorów ${ }^{58}$, McGregor i Elliot ${ }^{59}$, Elliot i Thrash ${ }^{60}$ oraz Martin i Marsh ${ }^{61}$. Ponieważ zachowanie agresywne ucznia ze SPE nie może być interpretowane przez nauczycieli jako celowe, intencjonalne, kontrolo-

52 C.E. Pugliese i in., Social Anxiety Predicts Aggression in Children with ASD, s. 1205-1213; K.E. Saylor, B.H. Amann, Impulsive Aggression as a Comorbidity, s. 19-25.

${ }_{53}$ C.N. Tsouloupas i in., Exploring the association between teachers' perceived student misbehaviour and emotional exhaustion: the importance of teacher efficacy beliefs and emotion regulation, Educational Psychology, 2010, 30(2), s. 173-189.

${ }^{54}$ C. Day, Q. Gu, Teacher Emotions: Well Being and Effectiveness, [w:] Advances in Teacher Emotion Research: The Impact on Teachers' Lives, red. P.A. Schutz, M. Zembylas, New York 2009, s. 15-31.

${ }_{55}$ A. Liljestrom, K. Roulston, K. Demarrais, "There's No Place for Feeling Like This in the Workplace, s. 275-291.

${ }^{56}$ R.E. Sutton, Teachers' anger, frustration, s. 259-274.

${ }^{57}$ R.E. Sutton, K.F. Wheatley, Teachers' emotions and teaching, s. 327-358.

58 A.G.C. Wright i in., The Pathoplastic Relationship Between Interpersonal Problems, s. 997-1024.

${ }^{59}$ H.A. McGregor, A.J. Elliot, The Shame of Failure, s. 218-231.

${ }^{60}$ A.J. Elliot, T.M. Thrash, The Intergenerational Transmission, s. 957-971.

${ }^{61}$ A.J. Martin, H.W. Marsh, Fear of Failure, s. 31-38. 
wane przez niego, zamiast złości pojawiającej się wobec uczniów, którym takie intencje można przypisać62 „włączają się" przewidywania negatywnych konsekwencji. Powstająca na skutek wykrytych wiązań "gra nauczycielskich lęków" opisuje sytuację silnego stresu, co idąc śladem badań Lecavalier i współautorów ${ }^{63}$ można ulokować w transakcyjnym modelu stresu (czy też ogólnie transakcyjnym modelu wymiany emocji) pomiędzy wszystkimi aktorami edukacji włączającej ${ }^{64}$. Taki stan osłabia pozytywne nastawienia do idei szkolnej inkluzji ${ }^{65}$, utrudnia praktyczną realizację jej założeń, osłabia nadzieję na jej sukces.

\section{Wnioski}

Prezentowane wyniki badań własnych dowodzą, że staż pracy nauczycieli i wraz z nim posiadane doświadczenia $\mathrm{w}$ pracy $\mathrm{z}$ uczniem $\mathrm{z}$ różnymi typami SPE nie wiąże się z przewidywaniem lękotwórczych konsekwencji agresywnego zachowania uczniów. Taki stan odpowiada wynikom badań Avramidis i współautorów ${ }^{66}$, w których dowiedziono, że doświadczenie zawodowe nie wiąże się znacząco z postawami nauczycieli.

Mając na uwadze badania Clough i Lindsay ${ }^{67}$, stwierdzamy na podstawie wyników badań własnych, że choć mamy do czynienia z progresem przygotowania nauczycieli do realizacji założeń edukacji włączającej, to stan przygotowania do pracy z zachowującym się agresywnie uczniem ze SPE nadal jest daleki od ideału i wymaga ciągłego doskonalenia. Oczywiście, zachowanie agresywne uczniów z natury zdarzenia zawsze wywoła u nauczyciela frustrację, jednak należy dołożyć wszelkich starań, by w ocenie takiej sytuacji i generowanym jako jej skutek działaniu odrzucić wszelkie „wzmacniacze”.

Zwracamy uwagę, że w badanej grupie wszyscy nauczyciele uczestniczyli w krótkich szkoleniach związanych ze strategią pracy z agresją impulsywną ucznia ze SPE. W świetle wyników badań możemy stwierdzić, że ich efekt nie zmienił znacząco dynamiki emocji będącej przeszkodą w sku-

${ }^{62}$ J. Brophy, M. McCaslin, Teachers' Reports of How They Perceive and Cope with Problem Students, The Elementary School Journal, 1992, 93(1), s. 3-68

${ }^{63}$ L. Lecavalier, S. Leone, J. Wiltz, The impact of behaviour problems, s. 172-183.

64 D.K. Meyer, J.C. Turner, Re-conceptualizing emotion and motivation to learn in classroom contexts, Educational Psychology Review, 2006, 18(4), s. 377-390; J.S. Yoon, Teacher characteristics as predictors of teacher-student relationships, s. 485-493.

65 S. Chhabra, R. Srivastava, I. Srivastava, Inclusive education in Botswana, s. 219-228; B.G. Cook, D.L. Cameron, M. Tankersley, Inclusive teachers' attitudinal ratings, s. 230-238.

${ }^{66}$ E. Avramidis, P. Bayliss, R. Burden, A Survey into Mainstream Teachers' Attitudes Towards the Inclusion of Special Educational Needs in the Ordinary School in one Local Educational Authority, Educational Psychology 2000, 20(2), s. 191-211.

67 P. Clough, G. Lindsay, Integration and the Support Service. 
tecznym działaniu, być może z powodu zbyt krótkiej formy, niewykluczone jednak, że ze względu na niedopasowanie treści do nieuświadomionych potrzeb nauczycieli. Zatem: 1) rekomendujemy uwzględnienie w szkoleniach treningów podnoszenia samoświadomości emocjonalnej nauczycieli, szczególnie przez wyposażenie nauczycieli edukacji włączającej w umiejętność: a) identyfikacji własnych lęków, b) ich obiektywizacji i racjonalizacji, c) budowania strategii działania opartej na doświadczanych, nie przewidywanych zdarzeniach; 2) dalszej kolejności, w celu osłabienia potencjalnych lęków związanych z przewidywaniem dezaprobaty rodziców i przełożonych, w szkoleniach należy kształtować umiejętność otwartej komunikacji (także o doznawanych frustracjach) pomiędzy wszystkimi aktorami edukacji włączającej; 3) ponieważ zmiana w umiejętnościach zarządzania własnymi emocjami jest długim procesem, dziejącym się na tle zmieniającej się scenografii edukacji włączającej, rekomendujemy cykliczną powtarzalność wyżej wymienionych szkoleń.

Na zakończenie chcemy zwrócić uwagę na wysoki odsetek nauczycieli wskazujących $\mathrm{w}$ prezentowanych $\mathrm{w}$ tym artykule badaniach na rzucanie przedmiotami przez uczniów ze SPE w klasie, co zmusza do zadania kilku pytań, kierunkujących dalsze badania: 1) Jak to się dzieje, że dochodzi do takich zdarzeń na tyle często, by wygenerować nauczycielską frustrację? 2) Jakim algorytmem charakteryzują się te czyny? 3) Jak wygląda scenografia klasy szkolnej, w której do nich dochodzi? 4) Jaką rolę odgrywa ta scenografia w przebiegu tych czynów?

Odpowiedzi na te pytania, jako ważne dla powodzenia spektaklu edukacji włączającej, będziemy poszukiwać w dalszych badaniach, do czego zachęcamy także innych badaczy. Każdy aspekt poszukujący wiedzy o czynnikach warunkujących sukces edukacji włączającej będzie odpowiedzią na postulat Lindsay ${ }^{68}$ dogłębnego badania podmiotów i czynników zaangażowanych w inkluzję, którzy wspierają optymalną edukację dzieci ze SPE, a w konsekwencji opracowanie podejścia opartego na dowodach.

\section{BIBLIOGRAFIA}

Angold A., Costello J.E., Erkanli A., Comorbidity, Journal of Child Psychology and Psychiatry, 1999, 40(1).

Avramidis E., Bayliss P., Burden R., A Survey into Mainstream Teachers' Attitudes Towards the Inclusion of Special Educational Needs in the Ordinary School in one Local Educational Authority, Educational Psychology, 2000, 20(2).

${ }^{68}$ G. Lindsay, Educational psychology and the effectiveness of inclusive education/mainstreaming, British Journal of Educational Psychology, 2007, 77, s. 1-24. 
Avramidis E., Kalyva E., The influence of teaching experience and professional development on Greek teachers' attitudes towards inclusion, European Journal of Special Needs Education, 2007, 22(4).

Avramidis E., Norwich B., Teachers' attitudes towards integration / inclusion: a review of the literature, European Journal of Special Needs Education, 2010, 17(2).

Bakhshani N.-M., Attention-Deficit/Hyperactivity Disorder (ADHD) and High Risk Behaviors, International Journal of High Risk Behaviors \& Addiction, 2013, 2(1).

Brackett M.A., Patti J., Stern R., Rivers S.E., Elbertson N.A., Chisholm C., Salovey P., A sustainable, skill-based approach to building emotionally literate schools, [w:] Handbook for Developing Emotional and Social Intelligence: Best Practices, Case Studies, and Strategies, red. M. Hughes, H.L. Thompson, J.B. Terrell, CA: Pfeiffer, San Francisco 2009.

Brophy J., McCaslin M., Teachers' Reports of How They Perceive and Cope with Problem Students, The Elementary School Journal, 1992, 93(1).

Caena F., Teacher Competence Frameworks in Europe: policy-as-discourse and policy-as-practice, European Journal of Education, 2014, 49 (3).

Chang M.- L., An appraisal perspective of teacher burnout: Examining the emotional work of teachers, Educational Psychology Review, 2009, 21(3).

Chang M.-L., Davis H.A., Understanding the role of teacher appraisals in shaping the dynamics of their relationships with students: Deconstructing teachers' judgement of disruptive behavior/ students, [w:] Advantages in teacher emotion research: The impact on teachers' lives, red. P.A. Schutz, M. Zembylas, Springer, New York 2009.

Chhabra S., Srivastava R., Srivastava I., Inclusive education in Botswana: the perceptions of school teachers, Journal of Disability Policy Studies, 2010, 20.

Clough P., Lindsay G., Integration and the Support Service. Changing Roles in Special Education, NFER-NELSON, Slough Winsdor 1991 (Taylor \& Francis e-Library, 2004).

Connor D.F., Chartier K.G., Preen E.C., Kaplan R.F., Impulsive aggression in attention-deficit/ hyperactivity disorder: Symptom severity, co-morbidity, and attention-deficit/hyperactivity disorder subtype, Journal of Child Adolescent Psychopharmacology, 2010, 20(2).

Cook B.G., Cameron D.L., Tankersley M., Inclusive teachers' attitudinal ratings of their students with disabilities, Journal of Special Education, 2007, 40(4).

Crick R.D., Key Competencies for Education in a European Context: narratives of accountability or care, European Educational Research Journal, 2008, 7.

Day C., Gu Q., Teacher Emotions: Well Being and Effectiveness, [w:] Advances in Teacher Emotion Research: The Impact on Teachers' Lives, red. P.A. Schutz, M. Zembylas, Springer, New York 2009.

De Boer A., Pijl S.J., Minnaert A., Regular primary schoolteachers' attitudes towards inclusive education: a review of the literature, International Journal of Inclusive Education, 2010, 15(3).

Dillman D.A., Mail and internet surveys: The tailored design method. Second Edition, John Wiley \& Sons, Hoboken 2007.

EADSNE, Profile of Inclusive Teachers, European Agency for Development in Special Needs Education, Odense, Denmark 2012.

Elliot A.J., Thrash T.M., The Intergenerational Transmission of Fear of Failure, Personality and Social Psychology Bulletin, 2004, 30(8).

Elsabbagh M., Divan G., Koh Y.-J., Kim Y.S., Kauchali S., Marcín C., Montiel-Nava C., Patel V., Paula C.S., Wang C., Yasamy M.T., Fombonne E., Global Prevalence of Autism and Other Pervasive Developmental Disorders, Autism Research, 2012, 5(3).

Ellsworth P.C., Tong E.M.W., What does it mean to be angry at yourself? Categories, appraisals, and the problem of language, Emotion, 2006, 6 (4). 
Fayyad J., De Graaf R., Kessler R., Alonso J., Angermeyer M., Demyttenaere K., De Girolamo G., Haro J.M., Karam E.G., Lara C., Lépine J.-P., Ormel J., Posada-Villa J., Zaslavsky A.M., Jin R., . Cross-national prevalence and correlates of adult attention-deficit hyperactivity disorder, The British Journal of Psychiatry, 2007,190(5).

Fitzpatrick S.E., Srivorakiat L., Wink L.K., Pedapati E.V., Erickson C.A., Aggression in autism spectrum disorder: presentation and treatment options, Neuropsychiatric Disease and Treatment, 2016, 12.

Frenzel A.C., Teacher Emotions, [w:] International Handbook of Emotions in Education, red. P.A. Alexander, R. Pekrun, L. Linnenbrik-Garcia, Routledge, London 2014.

Gajdzica Z., Opinie nauczycieli szkót ogólnodostępnych na temat edukacji włączającej uczniów z lekkim upośledzeniem umystowym w kontekście toczacej się reformy ksztatcenia specjalnego, [w:] Uczeń z niepełnosprawnościa, red. Z.Gajdzica, Wydawnictwo Wyższej Szkoły Humanitas, Sosnowiec 2011.

Hargreaves A., Mixed emotions: Teachers' perceptions of their interactions with students, Teaching and Teacher Education, 2000, 16.

Hastings R.P., Oakford S., Student Teachers' Attitudes Towards the Inclusion of Children with Special Needs, Educational Psychology, 2003, 23.

Hill A.P., Zuckerman K.E., Hagen A.D., Kriz D.J., Duvall S.W., van Santen J., Nigg J., Fair D., Fombonne E., Aggressive Behavior Problems in Children with Autism Spectrum Disorders: Prevalence and Correlates in a Large Clinical Sample, Research in Autism Spectrum Disorders, 2014, 8(9).

Hubbard J.A., McAuliffe M.D., Morrow M.T., Romano L.J., Reactive and proactive aggression in childhood and adolescence: Outcomes, processes, experiences, and measurement, Journal of Personality, 2010, 78(1).

Jensen P.S., Youngstrom E.A., Steiner H., Findling R.L., Meyer R.E., Malone R.P., Carlson G.A., Coccaro E.F., Aman M.G., Blair J., Dougherty D., Ferris C., Flynn L., Green E., Hoagwood K., Hutchinson J., Laughren T., Leve L.D., Novins D.K., Vitiello B., Consensus report on impulsive aggression as a symptom across diagnostic categories in child psychiatry: Implications for medication studies, Journal of the American Academy of Child and Adolescent Psychiatry, 2007, 46(3).

Jennings P.A., Greenberg M.T., The prosocial classroom: Teacher social and emotional competence in relation to student and classroom outcomes, Review of Educational Research, 2009, 79(1).

Johnson V.A., Kemp A.H., Heard R., Lennings C.J., Hickie I.B., Childhood-versus Adolescent-Onset Antisocial Youth with Conduct Disorder: Psychiatric Illness, Neuropsychological and Psychosocial function, PLoS ONE, 2015, 10(4), e0121627, https://dx.doi. org/10.1371\%2Fjournal.pone.0121627, [dostęp: 20.03.2018].

Kanne S.M., Mazurek M.O., Aggression in Children and Adolescents with ASD: Prevalence and Risk Factors, Journal of Autism and Developmental Disorders, 2011, 41(7).

Keller M. M., Chang M.-L., Becker E.S., Goetz T., Frenzel A.C., Teachers' emotional experiences and exhaustion as predictors of emotional labor in the classroom: an experience sampling study, Frontiers in Psychology, 2014, 5.

Kuppens P., Van Mechelen I., Smits D.J.M., De Boeck P., The appraisal basis of anger: Specificity, necessity, and sufficiency of components, Emotion, 2003, 3(3).

Kuyini A.B., Yeboah K.A., Das A.K. Alhassan A.M., Mangope B., Ghanaian teachers: competencies perceived as important for inclusive education, International Journal of Inclusive Education, 2016, 20(10).

Lecavalier L., Leone S., Wiltz J., The impact of behaviour problems on caregiver stress in young people with autism spectrum disorders, Journal of intellectual disability research, 2006, 50 (Pt3), 172-183, https:/ / doi.org/10.1111/j.1365-2788.2005.00732.x, [dostęp: 21.03.2018]. 
Liljestrom A., Roulston K., Demarrais K., "There's No Place for Feeling Like This in the Workplace": Women Teachers' Anger in School Settings, [w:] Emotion in education, red. P.A. Schutz, R. Pekrun, San Diego 2007.

Lindsay G., Educational psychology and the effectiveness of inclusive education/mainstreaming, British Journal of Educational Psychology, 2007, 77.

Lyall K., Croen L., Daniels J., Fallin M.D., Ladd-Acosta C., Lee B.K., Park B.Y., Snyder N.W., Schendel D., Volk H., Windham G.C., Newschaffer C., The Changing Epidemiology of Autism Spectrum Disorders, Annual Review of Public Health, 2017, 38.

MacFarlane K., Woolfson L.M., Teacher attitudes and behavior toward the inclusion of children with social, emotional and behavioral difficulties in mainstream schools: An application of the theory of planned behaviour, Teaching and Teacher Education, 2013, 29.

Mansfield C.F., Beltman S., Price A., McConney A., "Don't sweat the small stuff:" Understanding teacher resilience at the chalkface, Teaching and Teacher Education, 2012, 28(3).

Martin A.J., Marsh H.W., Fear of Failure: Friend or Foe?, Australian Psychologist, 2003, 38(1).

Mazurek M.O., Kanne S.M., Wodka E.L., Physical aggression in children and adolescents with autism spectrum disorders, Research in Autism Spectrum Disorders, 2013, 7(3).

McGregor H.A., Elliot A.J., The Shame of Failure: Examining the Link Between Fear of Failure and Shame, Personality and Social Psychology Bulletin, 2005, 31(2).

Meyer D.K., Turner J.C., Re-conceptualizing emotion and motivation to learn in classroom contexts, Educational Psychology Review, 2006, 18(4).

Monahan R.G., Marino S.B., Miller R., Teacher attitudes toward inclusion: Implications for teacher education in schools 2000, Education, 1996, 117(2).

Mrug S., Molina B.S.G., Hoza B., Gerdes A.C., Hinshaw S.P., Hechtman L., Arnold L.E., Peer Rejection and Friendships in Children with Attention-Deficit/Hyperactivity Disorder: Contributions to Long-Term Outcomes, Journal of Abnormal Child Psychology, 2012, 40(6).

Newschaffer C.J., Croen L.A., Daniels J., Giarelli,E. Grether J.K., Levy S.E., Mandell D.S., Miller L. A., Pinto-Martin J., Reaven J., Reynolds A.M., Rice C.E., Schendel D., Windham G.C., The Epidemiology of Autism Spectrum Disorders, Annual Review of Public Health, 2007, 28.

Niemeyer J.A., Proctor R., The influence of experience on student teachers' beliefs about inclusion, Journal of Early Childhood Teacher Education, 2002, 23(1).

Nijmeijer J.S., Minderaa R.B., Buitelaar J.K., Mulligan A., Hartman C.A., Hoekstra P.J., Attention-deficit/hyperactivity disorder and social dysfunctioning, Clinical Psychology Review, 2008, 28(4).

Perry C., Ball I., Dealing constructively with negatively evaluated emotional situations: the key to understanding the different reactions of teachers with high and low levels of emotional intelligence, Social Psychology of Education, 2007, 10(4).

Pugliese C.E., White B.A., White S.W., Ollendick T.H., Social Anxiety Predicts Aggression in Children with ASD: Clinical Comparisons with Socially Anxious and Oppositional Youth, Journal of Autism and Developmental Disorders, 2013, 43(5).

Poulou M., Norwich B., Cognitive, Emotional and Behavioural Responses to Students with Emotional and Behavioural Difficulties: A model of decision-making, British Educational Research Journal, 2010, 28(1).

Pouw L.B.C., Rieffe C., Oosterveld P., Huskens B., Stockmann L., Reactive/proactive aggression and affective/cognitive empathy in children with ASD, Research in Developmental Disabilities, 2013, 34(4).

Saylor K.E., Amann B.H., Impulsive Aggression as a Comorbidity of Attention-Deficit/Hyperactivity Disorder in Children and Adolescents, Journal of Child and Adolescent Psychopharmacology, 2016, 26(1). 
Scruggs T.E., Mastropieri M.A., Teacher perceptions of mainstreaming inclusion, 1958-1995: A research synthesis, Exceptional Children, 1996, 63(1).

Silva P., Neves I.P., Power and Control in the Classroom: Understanding Students' Disruptive Behaviours, Pedagogies: An International Journal, 2007, 2(4).

Sutton R.E., Teachers' anger, frustration, and self-regulation, [w:] Emotion in education, red. P.A. Schutz, R. Pekrun, CA: Academic Press, San Diego 2007.

Sutton R.E., Wheatley.K.F., Teachers' emotions and teaching: A review of the literature and directions for future research, Educational Psychology Review, 2003,15 (4).

Totsika V., Hastings R.P., Emerson E., Lancaster G.A., Berridge D.M., A population-based investigation of behavioural and emotional problems and maternal mental health: associations with autism spectrum disorder and intellectual disability, The Journal of Child Psychology and Psychiatry, 2011, 52(1).

Tsouloupas C.N., Carson R.L., Matthews R., Grawitch M.J., Barber L.K., Exploring the association between teachers' perceived student misbehaviour and emotional exhaustion: the importance of teacher efficacy beliefs and emotion regulation, Educational Psychology, 2010, 30(2).

Unianu E.M., Teachers' attitudes towards inclusive education, Procedia - Social and Behavioral Sciences, 2012, 33.

Wesley P.W., Buysse V., Tyndall S., Family and professional perspectives on early intervention: An exploration using focus groups, Topics in Early Childhood Special Education, 1997, 17(4).

Wigle S.E., Wilcox D.J., Teacher and administrator attitudes toward full inclusion in rural mid-America, Rural Special Education Quarterly, 1997, 16(1).

Wright A.G. C., Pincus A.L., Conroy D.E., Elliot A.J., The Pathoplastic Relationship Between Interpersonal Problems and Fear of Failure, Journal of Personality, 2009,77(4).

Valli L., Buese D., The changing roles of teachers in an era of high-stakes accountability, American Educational Research Journal, 2007, 44(3).

Vitaro F., Brendgen M., Tremblay R.E., Reactively and proactively aggressive children: Antecedent and subsequent characteristics, The Journal of Child Psychology and Psychiatry, 2002, 43 (4).

Yasutake D., Lerner J., Teachers' Perceptions of Inclusion for Students with Disabilities: A Survey of General and Special Educators, Learning Disabilities: A Multidisciplinary Journal, 1996, 7(1).

Yoon J.S., Teacher characteristics as predictors of teacher-student relationships: Stress, negative affect, and self-efficacy, Social Behavior and Personality: an international journal, 2002, 30(5). 